
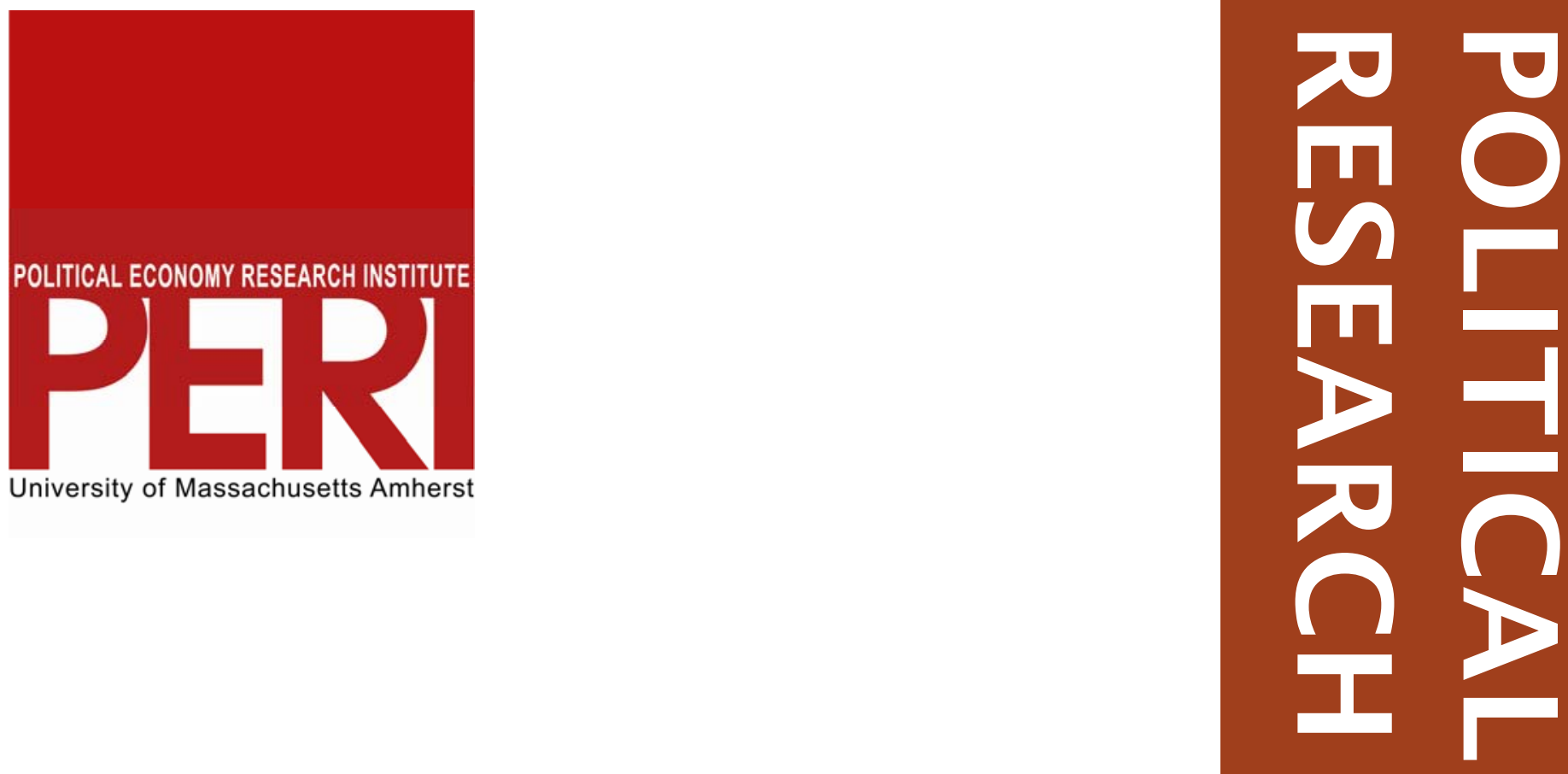

Current Global Imbalances and the Keynes Plan

\author{
Lilia Costabile
}

December 2007

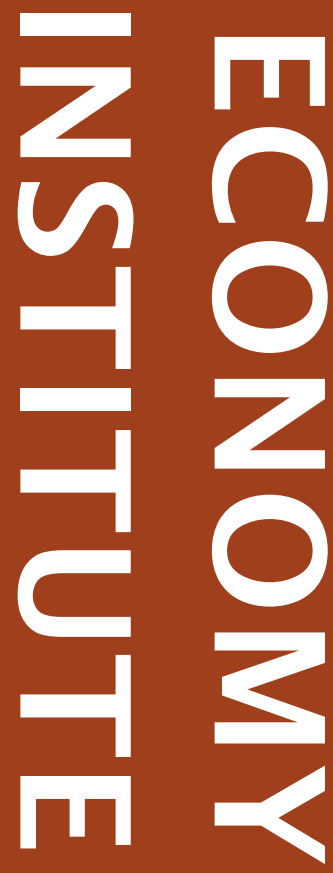

Gordon Hall

418 North Pleasant Street

Amherst, MA 01002

Phone: 413.545 .6355

Fax: 413.577 .0261

peri@econs.umass.edu

www.peri.umass.edu 


\section{Current global imbalances and the Keynes Plan.}

Lilia Costabile

\section{Introduction.}

The current state of the international economy is characterised by well-known "global imbalances"1. Facts include: (i) wide and persistent current account deficits run by the US, with correspondingly high surpluses in some emerging economies; (ii) large accumulation of US financial assets in international portfolios, particularly in the balance sheets of some emerging economies' Central Banks (China, India, Brazil, Russia etc.); (iii) other relevant accompanying facts, such as high expenditure, both private and public, accompanied by low saving rates in the US and high saving rates in the developing countries; a tendency for emerging economies to peg their currencies to the US dollar, etc.

Remedies to this unbalanced situation are now under scrutiny, in order to face or avoid what is commonly defined (Roubini and Setzer, 2005) as a "hard landing" in the US economy (i.e. falling domestic demand, reduced saving inflows and rising interest rates, etc.). In turn, falling demand in the US may impose severe worldwide recession, given the role of the US economy as the world's "engine of growth". Consequently, countries get stuck in a sort of suboptimal equilibrium, to the

- Dipartimento di Economia, Università di Napoli Federico II. I wish to thank Marcello De Cecco, Adriano Giannola, Jeff Harcourt, Julio Lopes, Carlo Panico, Roberto Scazzieri and Robert Skidelsky for reading and commenting on a previous version of this article. Thanks also go to Sam Bowles, Gerald Epstein, Peter Skott, Salvatore Vinci and other people who participated at the seminars and conferences (held in Naples, Rome, Amherst and Kansas City in 2006 and 2007) where previous versions have been presented. The responsibility for any remaining errors is mine.

${ }^{1}$ For an early diagnosis see Godley (1995). 
point that the international situation has been depicted by some observers as a "balance of financial terror" (Summers, 2004).

There is an ongoing debate on whether the world economy can "decouple" from a slowdown in the American economy (e.g. IMF, 2007). Still, there is little doubt that international adjustment imposes severe costs on the world economy, if only by affecting international debt/credit and trade relations via fluctuations in exchange rates.

The main objective of the present paper is to ask whether the "Keynes Plan", i.e. the Clearing (or Currency) Union scheme prepared by Keynes in the Forties, may still - at least in principle- provide useful remedies for this "terrorist" type of international imbalances. This will be done in two stages. Firstly, in section 2, the origins of international disequilibria are investigated. The purpose is to enquire whether current international monetary arrangements may generate some of the imbalances referred to above, because of the mechanisms built into them. Secondly, section 3 applies the remedies envisaged by the "Keynes Plan" to this source of international disequilibrium, and tries to assess their implications for current global imbalances. Section 4 concludes.

As Keynes himself suggested, it is not easy to disentangle the basic logic and the technical provisions of his plan from the specific type of disequilibrium characterising the international economy in the Forties (Keynes, 1971-89, from now on KCW, vol. 25, p.24). But it seems interesting to enquire whether the regulations and the adjustment rules that he devised may still apply to the imbalances that we face to-day and, thus, may have a more universal range of application than is usually thought. This article proposes an interpretation of current global imbalances based upon the nature of the international currency, its main objective being to present a "logical experiment", illustrating how alternative models of international financial organization may produce opposite results in the global economy.

\section{Global imbalances and key currencies.}


Because international exchanges are organised under the explicit or implicit regulations of an international monetary system, international monetary rules are one possible source of international imbalances, which is worth investigating in details, and in isolation from other possible sources.

Why is a monetary economy different from a barter economy? The basic reason is that an international means of payments allows the international economy to develop into a system of multilateral, rather than bilateral exchanges, as the international currency is a liquid asset, i.e. one accepted at low transactions costs. This has both advantages and disadvantages. Advantages include well-known efficiency gains, as a "double coincidence of wants" is not needed in a monetary economy. However, the existence of money may be a potential factor of disequilibrium in international transactions, depending on the nature of the international currency. As Keynes noticed, "the problem of maintaining equilibrium in the balance of payments between countries has never been solved, since methods of barter gave way to the use of money and bills of exchanges" (KCW, 25, p.21). This diagnosis, as we will try to show, is still valid to-day.

In principle, a variety of mediums can function as the international money (gold, national currencies, etc). Different consequences arise depending upon the specific medium performing this role. This is the crucial point where the current international monetary system and Keynes's Currency Union system part company. This section explores the working of the international monetary system as it is organised to-day. The characters of the alternative organization under the provisions of the Keynes Plan, which will be explored more thoroughly in the next section, are signalled here at the appropriate junctures. 
In the current financial organization of international transactions, the national currencies of some individual countries work as the international money ${ }^{2}$. Keynes, by contrast, proposed that the international money should be a supra-national money, issued by a supra-national agency.

National currencies working as international money have been sometimes called "key currencies", and "key countries" are the nations issuing them (Williams, 1937, 1949) ${ }^{3}$. I will use this terminology in what follows, and refer to a key currency as a $\mathrm{KC}$.

Historically, key-currency systems have functioned under the alternative regimes of convertibility and inconvertibility. Under a gold-exchange standard regime, a national currency is accepted as a substitute for gold, since the issuing country promises "convertibility", i.e. it promises to convert into gold any amount of its own currency, on demand, at a fixed rate. Alternatively, a national currency may work as the international money without promising convertibility into gold, or any other fixed anchor. This has been the case with the US dollar ever since the collapse of the BrettonWoods agreements in the Seventies, when the international system effectively evolved from a dollar-gold standard regime into a dollar standard. The essential point to stress at this stage is that,

2 Classic references are Cohen, 1971; McKinnon, 1979; Kindleberger, 1981a; Aliber, 1982; Krugman, 1984.

${ }^{3}$ Williams' "key currency approach" was formulated in the thirties (in 1932-33, if not before: James, 1996, p.65 and 628, fn.12). Williams' Plan appeared in Spring 1943. According to several authors (James,1996, pp. 65-66; Meltzer, 2003, p.585; Asso and Fiorito, forthcoming), the key currency idea gradually won approval, and finally "won out" over the Keynes and the White Plans in the factual implementation of the Bretton Woods system. Without being concerned with the details of Williams' Plan, I borrow his term "key currency" as a short name for the national currency serving as the international money. 
both with and without convertibility, the international currency comes into existence as the debt of the Central Bank of a key country.

An international monetary system based upon key currencies is asymmetric. As a first approximation, this happens because international liquidity remains dependent on the policies of the issuing countries, either because of their control over large gold reserves, to which they promise to give access via convertibility, or because key currencies function as fiat money, as it happens in the post-Bretton Woods era. The asymmetric nature of key currency regimes will emerge more clearly from the following analysis of the asymmetries generated by its working. In order to focus on the basic logic of the argument, it is assumed here that the world is inhabited by one K country, issuing the key currency, and one $\mathrm{J}$ country, issuing "own currency". However, reference is made to a multiplicity of $\mathrm{J}$ countries in the illustrating historical examples.

(1) The international currency is widely used in international transactions, as the currency in which payments are made (vehicle currency), and in which the countries' imports are quoted (quotation currency). Also, it becomes widely used in international lending-borrowing contracts, both of the short and the long-term variety. The role of key currencies as "reserve currencies" naturally follows from their pivotal role as the international means of payments: because of non-synchronisation of international sales and purchases, individual countries need to accumulate international reserves, just as an individual agent keeps a reserve of purchasing power in the form of "liquid" assets for transaction and precautionary purposes. Thus, Central Banks "institutionally" need to keep reserves in $\mathrm{KC}$ denominated assets. Other motivations may also be at work: firstly, countries different from the key countries, particularly if they are developing or emerging economies, have strong incentives to accumulate reserves in order to avoid an appreciation of their national currencies (KC depreciation) for competitiveness reasons. Moreover, Central Banks' precautionary demand may rise in periods of turbulence in financial markets, as they buy reserves as an insurance device 
against speculative attacks. These motivations may have comparatively different weights in different historical periods; but, irrespective of the changing importance of these alternative motivations, what emerges is the necessity, for any country that is not a "key" country, to buy KCdenominated reserves. Under the current international monetary regime, this circumstance confers upon key countries "a leading role in international affairs, with other currencies holding their reserves largely in those currencies" (James, 1996, p.30).

Thus, in this monetary system, an international (private and institutional) demand for the national currency of one country is generated. This confers upon this country the asymmetric position of widely selling its currency to the world.

By contrast, as we will see in the next section, the logic of the Keynes Plan does not contemplate this privileged position for any national country; in particular, it does not contemplate the holding, in Central Banks' portfolios, of foreign countries' currencies as reserves.

(2) In the international economy, money buys goods. Indeed, the only thing country J can give in exchange for the K currency that it needs are the goods that it produces, since its own currency- not being an international currency- is worthless for country K.

Country K may be viewed as the provider of "the public good of international money", although a more realistic interpretation is that $\mathrm{K}$ provides "the private good for itself of seignorage, which is the profit that comes to the signeur, or sovereign power, from the issuance of money" (Kindleberger 1981, p. 248). Thus, the world demand for the international currency confers upon country K the advantage of commanding part of country J's product simply by "printing” money: the international monetary system has a built-in mechanism whereby goods are transferred from country $\mathrm{J}$ to country K. 
This asymmetry is absent from the Keynes Plan, since, in its logic no "foreign currency" provides services as a key currency and reserve asset. The supra-national nature of the international money excludes seignorage accruing to any country.

(3) K's reliance on J's demand for its money makes its expansionary monetary policies relatively easy and convenient, so that the country is able to finance its demand flows towards the rest of the world, for both consumption and investment purposes. As this constraint on monetary policy is relaxed, country $\mathrm{K}$ may become prone to finance systematic current account deficits with the international money. Although alternative choices are possible, in the post World War II period, large current account deficits started in 1982 and have been a constant feature of the US economy since then (with the exception of 1991), hitting an all-time high of 6.5 per cent of GDP in 2006 (IMF, 2007).

Deficits must be matched by corresponding surpluses in J countries. As the world economy grows, it is beneficial for all if the international means of payment grows correspondingly, thereby preventing liquidity constraints on international transactions. The expansion of international liquidity contributes to export-led growth in J countries, because their current account surpluses are on the other side of K's deficit. They accordingly benefit as a result. But they are not in a position to do what $\mathrm{K}$ does, namely to issue the international money to pay for their deficits.

By contrast, the Keynes Plan requires that monetary policies for the international economy are implemented by a supra-national authority, according to rules which would be defined, and agreed upon in advance, by all countries joining the system.

(4) In country J, severe fiscal policies may be required in order to avoid the crowding out of exports. By contrast, in country $\mathrm{K}$ expansionary fiscal policies may have a useful role to play, as they may help offsetting the downward pressure on domestic production exerted by the country's 
presumably high propensity to import (or, in a long run perspective, by the high income elasticity of its imports).

By contrast, Keynes's Currency Union does not stimulate these asymmetric fiscal propensities. Because, as we will see in next section, all countries would be induced by the Plan's provisions to run balanced current accounts, they would neither need to compress domestic demand below domestic production, nor would they experience a downward pressure on domestic production.

(5) Reserve accumulation by country $\mathrm{J}$ is reflected in net external debt accumulation by country $\mathrm{K}$ This happens because country K can finance its imports of goods and services (in excess of its exports) only by borrowing from country J, i.e. by selling assets to J. Since selling assets implies borrowing from abroad, a trade deficit and a corresponding financial surplus amount to an addition to country K's external debit.

But, accounting aside, it is more interesting to ask what the economic mechanism behind these identities may be. Central Banks' behaviour is the driving mechanism, as it is more convenient for J's Central Bank to invest its reserves, rather than keep them barren in its vaults. Jacques Rueff provided a vivid illustration of this process in the course of a very interesting exchange with Fred Hirsh, about fifty years ago:

"What is the essence of the regime, and what is its difference from the gold standard? It is that when a country with a key currency has a deficit in its balance of payments - that is to say, the United States, for example- it pays the creditor country dollars, which end up in its central bank. But the dollars are of no use in Bonn, or in Tokyo, or in Paris. The very same day, they are relent to the New York money market, so that they return to the place of origin. Thus the debtor country does not lose what the creditor country has gained. So the key-currency country never 
feels the effect of a deficit in its balance of payments. And the main consequences is that there is no reason whatever for the deficit to disappear, because it does not appear.

Let me be more positive: if I had an agreement with my tailor that whatever money I pay him he returns to me the very same day as a loan, I would have no objection at all to ordering more suits from him" (Rueff and Hirsch, 1965, p. 3).

In the Bretton Woods era, European countries played the role of J countries, which other countries subsequently inherited, and will probably pass to other countries in the future (Dooley, Garber, Folkerts-Landau, 2003). But the "essence of the regime" has not changed. Because of the very "special international status of the U.S. dollar" (Bernanke, 2005), capital still flows from country J to country $\mathrm{K}$, with the further advantage that the ensuing downward pressure on interest rates stimulates growth in K. By contrast, domestic savings in $\mathrm{J}$ are diverted from domestic investment. Some scholars consider a disturbing paradox the fact that country J (i.e. the "poor" or developing country) is lending to $\mathrm{K}$, and not vice-versa. In current discussions of the US external position this point has been made by Roubini (2005) and the same point was previously made by Triffin (1984). But, to some extent, this paradox is a result of the working of the international monetary system: there is a tendency built in this system to confer the borrower/debtor position to country $\mathrm{K}$, because of the international status of its national currency and the consequent capital inflows so vividly illustrated by Rueff. Country $\mathrm{J}$ is in a less fortunate position: country K's Central Bank has no incentive to buy J's currency.

These disturbing paradoxes would disappear under the Keynes Plan, because no special international status would be bestowed on any national currency.

(6) For systematic borrowers, external debt may become unsustainable, if the debt/GDP ratio rises above some target level. However, one possible remedy for indebted key countries is capital gains 
from exchange rate adjustments. Country $\mathrm{K}$ benefits from a depreciation in its currency not simply because depreciation improves its competitiveness, but also by improving the country's net foreign position, via "valuation effects".

On the one hand, a depreciation of the international currency increases the value of country K's holdings of foreign assets. On the other hand, foreign creditors bought assets denominated in the key currency before its depreciation. Consequently, they now incur a loss which is obscured, but not eliminated, by the fact that the value of a unit of the $\mathrm{K}$ currency is still worth one unit after depreciation (and, consequently, the nominal value of K's liabilities is unchanged). Valuation effects determine a net wealth transfer from the rest of the world to country $\mathrm{K}$ (for other destabilising consequences of exchange rate adjustments see McKinnon and Schnabl, 2006). By contrast, should a depreciation of country J's currency occur, this would imply an increasing burden of its external debt. The underlying reason is that, because of the special international status of its currency, country K's debt is typically denominated in its own currency while J's debt is typically denominated in country K's currency. The inabilility of J countries to issue debt denominated in their own currencies (labelled the "original sin" by Eichengreen and others, 2003) thus implies an asymmetric effect of currency devaluations on the external position of the two types of countries.

This asymmetry could not materialize in the Currency Union scheme, where countries would all stand on a par in their international status. Moreover, as explicitly stated by Keynes, they could become debtors and creditors towards the International Bank as a whole, but not towards each other. Consequently, changes in exchange rates would not result in international redistributions of wealth.

The distinction between "Bretton-Woods" and the current regime is relevant in this context. In "Bretton-Woods", the US dollar had an "anchor", gold. This anchor imposed some degree of discipline on US external imbalances, although it may be disputed how much this constraint was 
biting in reality. In the post Bretton-Woods system, with inconvertibility, this discipline effect vanishes. Consequently, country $\mathrm{K}$ may become more willing to run into sustained external imbalances because, faced with a heavy net external position, it may more easily resort to depreciation as an instrument for external adjustment. The U.S. has been a net debtor country since the beginning of the Eighties, and valuation effects played a substantial role in the last decades, by contributing to $30 \%$ of the nation's financial adjustment (Gourinchas and Rey, 2005).

Summing up. Summers (2004) depicts the current situation as one in which "we (i.e., the US) rely on the costs to others of not financing our current account deficit as assurance that financing will continue". While the costs to others of continuing the policy of financing US deficits include earning negative real interest rates on US short-term securities (ibid.), and losing control on domestic monetary policy, the costs of discontinuing this policy may include sharply rising interest rates and a shrinking US market, with deflationary repercussions on the international economy.

In this section, the origins of this "balance of financial terror" have been traced back to the basic rules of the international monetary system, and, more precisely, to the role played by key currencies.

Thus, the next questions are: are there alternative monetary arrangements that may be substituted for the current "key currency" system? Specifically: would the world look different under the Keynes Plan? Would a "Keynesian international balance" be desirable? The next section tries to answer these questions.

\section{International balance and the 'Keynes Plan'.}

By international balance, Keynes meant something different from a "balance of financial terror". He defined "international balance" as a situation where countries live on balanced current accounts and capital flows are reduced to a minimum (KCW, 25, p.31; see De Cecco, 1979). He regarded the achievement of this type of international balance as the main objective of the Clearing Union 
scheme, that he proposed in order to shape the international monetary arrangements for the new age of peace following World War II. To reach international balance, Keynes devised a sophisticated international currency scheme, designed for taming conflicting national interests. This section tries to assess whether the basic logic of the Keynes Plan may apply to, and provide remedies for, international imbalances under more general circumstances than those facing the world economy in the Forties, and particularly for the imbalances that we are confronting to-day ${ }^{4}$.

This is obviously not an easy task. Keynes himself explained that: "Unfortunately, the technical task by which a state of international balance can be maintained once it has been reached, is made vastly more difficult by the circumstance that we start out from an existing state of extreme disequilibrium" (KCW, 25, p.24). For our present purposes, this implies that the logic of the Plan has to be "disentangled" from the specific characters of the international disequilibrium of the Forties, and that some important changes in the international scenario should be briefly signalled, before we can try and disclose its more universal implications.

Firstly, the international positions of some countries have been reversed, with the US, for example, being the creditor country at the time, in contrast with its role as the main debtor country to-day. Britain was then one of the main debtors, and Keynes's defence of British interests influenced his

\footnotetext{
${ }^{4}$ The different drafts of the Plan are considered here as a coherent whole, unless otherwise noticed. However, because Keynes's thinking about "future currency agreements" started in 1940, and did not stop at least until the Bretton Woods agreements were signed in 1944, his plan underwent several changes. These were a result of both evolving circumstances, and extensive exchanges with colleagues, Treasury and Bank of England officials, British politicians, and, later, with the American delegation. The evolution of the Keynes' Plan can be traced in KCW, vol. 25; see also: Harrod (1951); Horsefield (1969); R.F. Kahn in Thirlwall (1976); James (1996); Moggridge (1992); Skidelsky (2003).
} 
emphasis on the necessity that creditors should share with debtors the burden of international adjustment. Secondly, the world was facing specific problems in the aftermath of World-War II, such as the need to reconstruct Europe after wartime disruptions. At the financial level, the hot issue was the need to face the "scarce currency" problem (as the dollar then was) and, more generally, to prevent international liquidity constraints from curbing economic reconstruction and growth. Thirdly, most economists, including Keynes, were still recovering from the shock of the world depression of the Thirties, and thought that the main task facing the designers of the new international monetary order was to prevent the international transmission of deflationary impulses. Fourthly, the post-war financial architecture was seen by many as the product of Anglo-American wartime alliance (James, 1996) and there are hints that Keynes himself indulged to a vision of the Clearing Union as an institution to be dominated by a balance between Anglo-American interests 5 . In spite of these unavoidable historical roots and conditioning, it is my contention that the basic logic of Keynes Plan survives the specific purposes pursued by his author in the Forties. This can be seen by looking at its objectives, at its principles and technical devices and, finally, by developing its implications for the present state of the world economy.

(1) OBJECTIVES. The objective of the Plan was that of "devising a system by which a state of international balance may be maintained once it has been reached" (KCW, v.25, p.24, 1st draft). In

\footnotetext{
${ }^{5}$ The new Bank should come into existence at the initiative of the US and the UK as "joint founders of the Club", so that these two countries could "settle the charter and the main details of the new body without being subjected to the delays and confused counsels of an international conference"..."I conceive of the management and the effective voting power as being permanently Anglo-American" (KCW, vol.25, p.54-55, Second Draft; see also pp.73-74, $3^{\text {rd }}$ draft). However, it is well known that there was some degree of conflict between the US and Britain (Balogh, 1976; Skidelsky, 2003; Harcourt and Turnell, 2005).
} 
this situation external surpluses and deficits would be reduced to a minimum, as economies, or groups of economies ${ }^{6}$, would live on virtually balanced accounts. Although it might be impossible in practice to eradicate international imbalances completely, the international monetary system should work so as to curb, rather than amplify, their emergence.

One reason why a "Keynesian international balance" is desirable is that that, in such a situation, every country (or group of countries) would live within the limits set by its own resources. This feature of Keynes's plan has relevant welfare (and, possibly, political) implications. On the one hand countries, freed from the need to run systematic external surpluses, would not pursue aggressive commercial policies, such as those broadly defined as Mercantilist. Hence, domestic resources could be devoted to the satisfaction of citizens' needs, and Governments would be free to pursue the domestic objectives of "providing continuous good employment at a high standard of living" (KCW, 25, p.27, 1st draft) ${ }^{7}$. Symmetrically, no country could run systematic deficits, which would allow them to live "profligately beyond their means" (KCW, 25, p.30). Internal resources would constrain alternative domestic goals. This may eventually help nations to perceive more clearly the trade-offs between alternatives (consumption, investment and government expenditures, the latter either for welfare purposes or for the financing of wars). Possibly, the clear perception of these trade-offs would enable countries to make democratically accountable choices.

Another important reason why a "Keynesian international equilibrium" is desirable is that external surpluses and deficits tend to destabilise the world economy, whether in a contractionist or an

\footnotetext{
${ }^{6}$ Keynes argued that "it would be preferable, if it were possible, that the members [of the Clearing Union] should, in some cases at least, be groups of countries rather than separate units" (e.g. North American countries, South and Central America, the Sterling area... (KCW, 25, p.56).

${ }^{7}$ On the relation between "national self-sufficiency", full employment and domestic social policies in Keynes see also Skidelsky (2003); Vines (2003).
} 
inflationist direction, by facilitating the international transmission of imbalances. Keynes was mostly concerned with deflations, because he had lived the experience of the Twenties and Thirties. He argued that the surplus countries (as they then were), the US and France, had imparted a "contractionist pressure" on the world by sterilising their gold inflows, thus preventing the increase in their international reserves from initiating a monetary expansion ( $\mathrm{KCW}, 25, \mathrm{p} .273)$. The problem was aggravated by capital flights from deficit to surplus countries. This determined world-wide recession. Keynes intended to substitute "an expansionist, in place of contractionist, pressure on world trade" (KCW, vol.25, p.46, $2^{\text {nd }}$ draft). His "Clearing Union Plan" can thus be considered as a means to achieve, via the international route, the same full-employment objectives that he also invocated in the General Theory.

Contrary to Keynes's expectations, after World War II deflation failed to materialize. Ever after the initial period of post-war reconstruction in Europe, the world witnessed an expansion of international liquidity, which has been interpreted by many scholars as the means for running US payments deficits (e.g. Eichengreen, 1996, pp. 115-116). This imposed an expansionary impulse on the international economy, both in the Bretton Woods and in the post-Bretton Woods periods. Although Keynes conceived of his Clearing Union system as a remedy for contractionist pressures, we will see that the logic of his plan would curb the international transmission of both contractions and excessive expansions, because its foundational principles and basic provisions were such as to make both surpluses and deficits (i.e. the very roots of destabilizing pressures) difficult to run.

(2) MEANS. What kind of principles should underlie the international monetary system, and which technical devices should be implemented to the purpose of curbing international imbalances?

Keynes proposed two basic principles: the "Banking Principle" and what he defined "one-way" gold convertibility.

The logic of the Banking Principle implies that liquidity should have the nature of credit money. Because the transactions to be financed through this medium are international transactions, the 
issuing institution should be a supra-national Bank, the International Clearing Bank (ICB), whose establishment would be the task of the International Clearing Union, itself a supra-national agency. Thus, the international money would be the liability of the ICB, not of any individual nation. Consequently, there would be no demand for any "key currency" as the means for international payments and, consequently, as a reserve in Central Banks' portfolios. Actually, the need for holding official reserves would disappear altogether (as "Central banks would buy and sell their own currencies amongst themselves only against debits and credits to their accounts to the Clearing Bank, designated Clearing accounts”, KCW, 25, p.34).

The logic of the Banking Principle also implies that bank money should be created as overdraft facilities. Keynes's international money (called the bancor) would be created by means of overdraft facilities provided by the ICB to the Central Banks of the adhering countries (Member Banks), each of them having a claim to overdraw according to its own "index quota". Quotas, which would represent a claim to borrow at the ICB, would be proportional to (specifically, one half of) the average of each country's total trade for the previous five years. These rules would be agreed upon by all countries entering the Union, and would equally apply to all of them. No country would be favoured or discriminated against, each falling under these quota regulations, which would determine the creation of international liquidity. Rules, rather than national discretion, would be the norm for the creation of international liquidity ${ }^{8}$.

As is well known, credit money is created when an agent enters a debit relation with the bank. Under the Plan's provisions, this could only happen when a deficit country borrowed from the ICB in order to finance its excess demand for a foreign currency. Consequently, one implication of the

\footnotetext{
${ }^{8}$ In his third drafts Keynes moved somewhat towards discretion, although mostly in the penalties to be inflicted on countries in external disequilibrium (Moggridge,1992, p.677).
} 
Plan is that balancing transactions between any two countries would not result in the creation of international liquidity, as they would simply be cleared between the Central Banks concerned, operating on their accounts with the $\mathrm{ICB}^{9}$. Thus, in the hypothetical case that all member countries were in external equilibrium at the end of the accounting period, the sum of bancor balances would be equal to zero (as duly noticed by Skidelsky, 2003, p.677). In all other cases, only residual transactions, i.e. those which would not spontaneously balance, would be settled by Member Banks by buying or selling their own currencies from the I.C.B. For instance, a deficit country would settle its balance by withdrawing parts of its overdraft facilities, up to the maximum limit set by its index quota. Correspondigly, surplus countries would accumulate unused overdrafts. Thus, the logic of the Banking Principle implies that the creation of international liquidity would be limited to unbalancing transactions.

Because deposits of bank money (credits and debits) would be created by external deficits and surpluses, and extinguished by their liquidation, international liquidity would be absolutely elastic, i.e. automatically adjusted to the needs of $\operatorname{trade}^{10}$. Thus, the logic of the Banking Principle, applied

\footnotetext{
${ }^{9}$ When a member of the public of one country (e.g. Britain) demands a foreign currency (e.g. dollars) to pay for a specified purpose, it makes an application to the bank of England through its bank. The balances due to or from any foreign state will be cleared between the central banks concerned, operating on their accounts with the ICB (Keynes, 25, p.61 n.).
}

${ }^{10}$ As Keynes noticed in his "comparative analysis of the British project for a Clearing Union (C.U.) and the American project for a Stabilisation Fund (S.F.): "In C.U. the quota changes pari passu with the volume of foreign trade. This has the great advantage that the volume of new international currency outstanding is a function of the volume of trade which it is required to finance" (KCW, vol.25, p.217). See also KCW, 25, p. 140: “ Mr. Keynes, in reply to a question as to how these proposals differed from the old theory of the gold standard, remarked that...'Bancor' could be 
to the international economy, responds to Keynes's desideratum that contractionist pressures on the international economy, arising from liquidity constraints, should be avoided (KCW, 25, p.140; p.160).

But the Plan also included measures apt to curb the opposite type pressure, i.e. inflationary pressures $^{11}$. This can be seen by considering how the Plan combined the confinement of liquidity creation to the financing of unbalancing transactions, as illustrated above, with a strong pressure on countries to avoid these unbalances: against the danger that countries may acquiesce to, or willingly run, deficits and surpluses, the Plan introduced severe discipline devices on debtors and creditors, operating via both credit rations and price incentives. Debtors could only borrow within the maximum limit set by their index quotas, and only at rising interest rates; creditors would be required to transfer to the Union any surplus above their quota, and also to pay charges to the Union if their credits exceeded one quarter of these quotas. Thus, the regulation of international liquidity and the prevention of international disequilibria would effectively go hand in hand, in the logic of the Keynes Plan, and curb both inflationary and deflationary pressures ${ }^{12}$.

acquired in return for gold, but gold could not be acquired in return for bancor. The quantity of bancor was absolutely elastic and in fact the proposal substituted bank money for gold, which would not in future limit the amount of money there would be" (Minutes of a meeting of the War cabinet Committee on Reconstruction Problems, 31 March 1942).

${ }^{11}$ The accusation was raised by American bankers that the Keynes Plan would be inflationary. Paradoxically, the same accusation had been raised against the gold exchange standard in the 1920s (James, 1996, p.65).

${ }^{12}$ The Banking Principle also excludes that the ICB may become insolvent, as explained by Keynes (KCW, 25, p.44): “This principle is the necessary equality of credits and debits, of assets and liabilities. If no credits can be removed outside the banking system but only transferred within it, 
Let us now consider the second Principle, i.e. one-way gold convertibility. This Principle implies that gold would play a rather peculiar role in this scheme. It would still be used as the unit of account of the bancor (KCW, 25, p.34); but Central Banks, while allowed to pay gold into the ICB in order to replenish their accounts, would not be allowed to withdraw it. Hence, gold would in fact gradually exit the international circulation and Member Banks' reserves ${ }^{13}$.

This aspect of the Keynes plan has not passed unnoticed. Commentators have rightly argued that Keynes's purpose was to de-monetise gold, the aim being to remove the incentives for Central Banks to hoard it (Skidelsky, 2003, p.677-78; James, 1996, p.36). This is coherent with these authors' interpretations, focusing on the anti-deflationary objectives that Keynes was pursuing in the Forties, and on his defence of the interests of debtor countries, as Britain there was. This interpretation is perfectly valid from an historical point of view, and perfectly responding to Keynes's own declared purposes: because creditors countries had imparted a deflationary pressure on the world economy by sterilising gold inflows, the first thing to do was to make their "liquidity

the bank itself can never be in difficulties. It can with safety make what advances it wishes to any of its customers with the assurance that the proceeds can only be transferred to the bank account of another customer".

${ }^{13}$ Robertson, commenting on this aspect of the Clearing Union Plan, illustrated with his usual cuteness the vanishing role of gold as a reserve asset: "A gold reserve which can never be paid out to anyone (except probably the International Bank of Mars) is an odd thought, but probably the right reductio ad absurdum" (KCW, vol. 25, p.67 letter from Robertson to Keynes 27 november 1941). In the logic of the Plan, the gold reserves of the entire global economy would eventually converge into the ICB's vaults. As to the uses to which this mass of gold could then be put, Keynes suggested international aid. 
preference" vacuous, by removing gold, the material object of their desires, form the international circulation. In this sense, gold was to be demonetised by fiat.

I subscribe to this interpretation as far as it goes. However, these interpreters have relatively underrated the other side of the Plan, relating to the role of national currencies. The Plan in fact envisaged a double demonetisation: what had to exit the international circulation and reserves was not just gold, but also any national currency which may otherwise come to assume the role of the international money. National currencies, while retaining their role as the medium of domestic transactions, would be demonetised (from the point of view of the international circulation), because the demand for these currencies as international currencies was to be abolished by fiat. "Key currencies" were to be a logical impossibility, and the international monetary system, for these reasons, was to be absolutely symmetric.

The symmetry property of the Keynes Plan has been noticed by some interpreters, and attributed to the provision of penalties both for debtors and creditors, as discussed above (James, 1996, p.36-37). But these interpretations, in my opinion, fail to put sufficient emphasis on the circumstance that the asymmetries, so to speak, would be cut at their roots: not only would international imbalances (as their normally arise between symmetric countries) be discouraged by means of the above mentioned penalties; most importantly, what would be disempowered is the basic source of international imbalances as described in section 2, i.e. the basic asymmetry between countries issuing the international money and countries deprived of this privilege.

Summing up, the monetary system envisaged by Keynes is symmetric for three reasons, i.e. because: (i) the link between the gold and international liquidity is severed, in the sense that the distribution of international liquidity becomes independent from the distribution of gold reserves among countries; (ii) national currencies stand on a par, since none of them is allowed to work as the international currency; (iii) finally, any remaining imbalances between countries (now made symmetric by the operation of the system), would be kept under control via the penalties envisaged 
by the Plan. Only the combination of these measures gives rise to international symmetry, while each measure taken in isolation is unable to generate this result.

(3) IMPLICATIONS. It is worthwhile to discuss the implications of this radical cut. This is done here by sketching the broad picture of a "conjectural history" of the international monetary system under the Keynes Plan.

Firstly, because the ICB would have been the only issuer of the international currency, the international money supply would have been regulated in the collective interest of member countries, or at least these countries might have exercised a more collective control over liquidity.

Secondly, because the international means of payments would be an international money, no "key country" would have had the privilege of imposing seignorage on the rest of the world. In other words, countries would not need to buy -with goods- the currency of one particular country.

Thirdly, debt-credit relations among individual countries would have been transformed into debtcredit relations with the ICB. As Keynes argued, "A country is in debit or credit with the Currency union as a whole" (KCW, 25, p.74, 3rd draft).

Fourthly, because the international currency would have the nature of credit money, reserve holdings by Member Banks would have disappeared altogether. Their demands for, and supplies of, foreign currencies would simply either cancel out at the ICB or, for countries in external disequilibrium, would give rise to a change in the amount of the available international credit. The role of international reserves (both for transaction purposes, and for precautionary motives) would simply vanish. The reasons (competitiveness or self-insurance) motivating the present very large foreign exchange holdings by the Central Banks of emerging economies are under investigations in current debates. Although this literature provides very interesting insights into the costs of reserve holdings (e.g. Rodrick, 2006), it does not raise the question why reserves should be held in the national currencies of some foreign country, and whether the related welfare losses could be 
avoided by some alternative international financial arrangements, such as, for instance, those envisaged by Keynes.

Finally, no country would be enabled to renege on its own debt. International redistributions of wealth via key-currency depreciations would disappear. Thus, while in the system we live in, "key countries" have an incentive to run external deficits (because they are aware that the corresponding external debts can be wiped out), in the Keynes Plan this adjustment mechanism is non-existent.

These are the basic reason why, under this Plan's provisions, the world would have probably been more balanced than the present one.

\section{Conclusions.}

I have argued in favour of the enduring relevance of the Keynes Plan as a remedy for international disequilibria. Although the Plan was devised to deal with international imbalances imputable to the role of gold in a regime of convertibility and resulting in deflationary pressures, I have argued that its logic is still valid to-day, when gold has long exited the international circulation, and convertibility has long been forgotten. Because the Keynes Plan may remedy some of the current international imbalances, it may still work as a source of useful inspiration for projecting international monetary arrangements or, at least, as a useful benchmark for assessing alternative adjustment projects.

Even at a time when the world was trying to build its own future along new lines, the Keynes Plan was, according to his author, "perhaps Utopian, in the sense not that it is impracticable, but that it assumes a higher degree of understanding, of the spirit of bold innovation, and of international cooperation and trust than it is safe or reasonable to assume". Nevertheless, Keynes considered it as "a good schematism by means of which the essence of the problem can be analysed"(KCW, 25, p.33). 
In the same vein, my main objective has been to present a "logical experiment", illustrating how alternative models of international financial organization may produce opposite results in the global economy.

One model relies on a national currency performing the role of the international money. By contrast, in the Keynes Plan both gold and national currencies should be demonetised for the purposes of international transactions, and replaced by a credit money, issued by a supra-national agency. This plan was intended as a means for promoting a symmetric monetary system and, through this route, a "Keynesian international balance", proposed here as a virtual alternative to the current situation.

Because the world currently lives in what has been defined a "balance of financial terror", the need for "financial disarmament" that motivated Keynes's proposal (KCW, 25, p.57) is now felt more than ever. 


\section{REFERENCES.}

Aliber, R.Z. (1982) "The evolution of currency areas. A speculation in monetary history", in Cooper, Kenen, Braga de Machedo and van Ypersele, The international monetary system under flexible exchange ates. Global, regional and national issues. Essays in Honour of Robert Triffin, Cambridge, MA, pp. 147-159.

Asso, P.F. and L. Fiorito (forthcoming), "A Scholar in Action in Interwar America. John H. Williams on trade theory and Bretton Woods, forthcoming in R.Leeson (ed.) Archival Insights Into the Evolution of Economics, London: Palgrave Macmillan.

Balogh, T. (1976), “Keynes and the International Monetary Fund”, in Thirlwall, A.P. (ed.), 1976.

Bernanke B.S. (2005), "The Global Saving Glut and the U.S. Current Account Deficit”, Remarks made at the Sandridge Lecture, Virginia Association of Economics, Richmond, Virginia, March 10, available at:

http://www.federalreserve.gov/boarddocs/speeches/2005/200503102/default.htm 
Cohen, B. (1971), The Future of Sterling as an International Currency, London, Macmillan.

De Cecco, M. (1979), "Origins of the post-war payments system", Cambridge Journal of Economics, 3, 49-61.

Dooley, M.P., D. Folkerts-Landau, P. Garber (2003), “An Essay on the Revived Bretton-Woods System”, NBER Working Paper No. 9971, September.

Eichengreen, B. (1996), Globalizing capital. A history of the International Monetary System, Princeton, Princeton University Press.

Eichengreen B., R.Hausmann and U.Panizza (2003), “Currency mismatches, debt intolerance and original sin: why they are not the same and why it matters", NBER, Working Paper n.10036.

Godley, W. (1995), “A Critical Imbalance in the US Trade”, Public Policy Brief 23, The Jerome Levy Institute.

Gourinchas P.O. and H. Rey (2005), "International financial adjustment", NBER, Working Paper No. 11155.

Harcourt, G.C. and G.C. Turnell (2005), “On Skidelsky’s Keynes”, Economic and Political Weekly, Vol. XL, n.47, November 19, pp.4931-4946.

Harrod, R. F. (1951), The life of John Maynard Keynes, London, Macmillan. 
Horsefield, J.K. (1969), The international Monetary Fund, 1945-1965, (vol.I, Chronicle) published by the International Monetary Fund.

IMF (2007), World Economic Outlook, April.

James, H. (1996), International Monetary Cooperation since Bretton Woods, Washinghton, D.C., International Monetary Fund, and New York Oxford, Oxford University Press.

Kahn, R. (1976), "Historical Origin of the International Monetary Fund”, in Thirlwall, A.P. (ed.), 1976.

Keynes, J.M. (1971-1989), The Collected Writings of J.M. Keynes, volumes I to XXX, edited by D.E. Moggridge, London, Macmillan.

Kindleberger, C.P (1981), "Dominance and leadership in the international economy: exploitation, public goods and free rides", International Studies Quarterly, vol.25, n. 2, Symposium in Honor of Hans J. Morgenthau, June, pp.242-254.

Krugman, P. (1984), “The International Role of the Dollar: Theory and Prospect”, in J.F.O. Bilson and R.C. Marston (eds.), Exchange rate theory and practice, Chicago and London, The University of Chicago Press.

McKinnon, R. (1979), “Money in International Exchange: The Convertible Currency System”, Oxford, Oxford University Press. 
McKinnon, R., and G. Schnabl (2006), "Devaluing the Dollar: A Critical Analysis of William Cline's Case for a New Plaza Agreement”, Journal of Policy Modeling, 28, (6) September, 683-94.

Meltzer A. (2003). A History of the Federal Reserve. Vol. 1. 1913 - 1951. Chicago and London: The University of Chicago Press.

Moggridge, D.E. (1992), Maynard Keynes. An economist’s biography, London, Routledge.

Rodrick, D. (2006), “The social cost of foreign exchange reserves”, NBER, Working Paper n.11952.

Roubini, N. and Setser, B. (2005), "Will the Bretton Woods 2 regime unravel soon? The risk of hard landing in 2005-2006", paper written for the Symposium on the 'revived Bretton Woods system: a new paradigm for Asian development?" organized by the Federal Reserve Bank of San Francisco and UC Berkeley, San Francisco, February, $4^{\text {th }}$. available at http://www.stern.nyu.edu/globalmacro/

Rueff J and F. Hirsch, (1965), The role and rule of gold. An argument, Princeton Essays on International Finance, n.47, June.

Summers, L. (2004), The US current account deficit and the global economy, The Per Jacobsson Lecture, Sunday, October 3, Washington, D.C., The Per Jacobson Foundation.

Skidelsky, R. (2003), John Maynard Keynes, 1883-1946. Economist, Philosopher, Statesman, London, Macmillan. 
Thirlwall, A.P. (1976) (ed.), Keynes and International Monetary Relations, London, Macmillan.

Triffin, R. (1984), “How the world entered 'infession': crisis management or fundamental reforms?", in Masera, R.S. and R. Triffin (1984), Europe's money. Problems of European monetary co-ordination and integration, Oxford, Clarendon Press.

Vines D. (2003), “John Maynard Keynes 1937-1946: the creation of modern international macroeconomics. A review article on John Maynard Keynes 1937-1946: Fighting for Britain by Robert Skidelsky”, Economic Journal, 2003, n.488, june, pp.F338-F361(1)

Williams, J.H. (1937), “The Adequacy of Existing Currency Mechanisms under Varying Circumstances", The American Economic Review, Papers and Proceedings, Vol. 27, No. 1, March, pp. 151-168; reprinted, under a different title, in Williams (1949), chap. 19.

Williams, J.H. (1949), Postwar Monetary Plans and Other Essay. Oxford: Blackwell. 


\section{FOOTNOTES}

${ }^{1}$ For an early diagnosis see Godley (1995).

${ }^{2}$ Classic references are Cohen, 1971; McKinnon, 1979; Kindleberger, 1981a; Aliber, 1982; Krugman, 1984.

${ }^{3}$ Williams' "key currency approach" was formulated in the thirties (in 1932-33, if not before: James, 1996, p.65 and 628, fn.12). Williams' Plan appeared in Spring 1943. According to several authors (James,1996, pp. 65-66; Meltzer, 2003, p.585; Asso and Fiorito, forthcoming), the key currency idea gradually won approval, and finally "won out" over the Keynes and the White Plans in the factual implementation of the Bretton Woods system. Without being concerned with the details of Williams' Plan, I borrow his term "key currency" as a short name for the national currency serving as the international money.

${ }^{4}$ The different drafts of the Plan are considered here as a coherent whole, unless otherwise noticed. However, because Keynes's thinking about “future currency agreements" started in 1940, and did not stop at least until the Bretton Woods agreements were signed in 1944, his plan underwent several changes. These were a result of both evolving circumstances, and extensive exchanges with colleagues, Treasury and Bank of England officials, British politicians, and, later, with the American delegation. The evolution of the Keynes' Plan can be traced in KCW, vol. 25; see also: Harrod (1951); Horsefield (1969); R.F. Kahn in Thirlwall (1976); James (1996); Moggridge (1992); Skidelsky (2003).

${ }^{5}$ The new Bank should come into existence at the initiative of the US and the UK as "joint founders of the Club", so that these two countries could "settle the charter and the main details of the new body without being subjected to the delays and confused counsels of an international conference"..."I conceive of the management and the effective voting power as being permanently Anglo-American" (KCW, vol.25, p.54-55, Second Draft; see also pp.73-74, $3^{\text {rd }}$ draft). However, it 
is well known that there was some degree of conflict between the US and Britain (Balogh, 1976; Skidelsky, 2003; Harcourt and Turnell, 2005).

${ }^{6}$ Keynes argued that "it would be preferable, if it were possible, that the members [of the Clearing Union] should, in some cases at least, be groups of countries rather than separate units" (e.g. North American countries, South and Central America, the Sterling area... (KCW, 25, p.56).

${ }^{7}$ On the relation between "national self-sufficiency", full employment and domestic social policies in Keynes see also Skidelsky (2003); Vines (2003).

${ }^{8}$ In his third drafts Keynes moved somewhat towards discretion, although mostly in the penalties to be inflicted on countries in external disequilibrium (Moggridge,1992, p.677).

${ }^{9}$ When a member of the public of one country (e.g. Britain) demands a foreign currency (e.g. dollars) to pay for a specified purpose, it makes an application to the bank of England through its bank. The balances due to or from any foreign state will be cleared between the central banks concerned, operating on their accounts with the ICB (Keynes, 25, p.61 n.).

${ }^{10}$ As Keynes noticed in his "comparative analysis of the British project for a Clearing Union (C.U.) and the American project for a Stabilisation Fund (S.F.): "In C.U. the quota changes pari passu with the volume of foreign trade. This has the great advantage that the volume of new international currency outstanding is a function of the volume of trade which it is required to finance" (KCW, vol.25, p.217). See also KCW, 25, p. 140: “Mr. Keynes, in reply to a question as to how these proposals differed from the old theory of the gold standard, remarked that...'Bancor' could be acquired in return for gold, but gold could not be acquired in return for bancor. The quantity of bancor was absolutely elastic and in fact the proposal substituted bank money for gold, which would not in future limit the amount of money there would be" (Minutes of a meeting of the War cabinet Committee on Reconstruction Problems, 31 March 1942). 
${ }^{11}$ The accusation was raised by American bankers that the Keynes Plan would be inflationary. Paradoxically, the same accusation had been raised against the gold exchange standard in the 1920s (James, 1996, p.65).

${ }^{12}$ The Banking Principle also excludes that the ICB may become insolvent, as explained by Keynes (KCW, 25, p.44): "This principle is the necessary equality of credits and debits, of assets and liabilities. If no credits can be removed outside the banking system but only transferred within it, the bank itself can never be in difficulties. It can with safety make what advances it wishes to any of its customers with the assurance that the proceeds can only be transferred to the bank account of another customer".

${ }^{13}$ Robertson, commenting on this aspect of the Clearing Union Plan, illustrated with his usual cuteness the vanishing role of gold as a reserve asset: "A gold reserve which can never be paid out to anyone (except probably the International Bank of Mars) is an odd thought, but probably the right reductio ad absurdum" (KCW, vol. 25, p.67 letter from Robertson to Keynes 27 november 1941). In the logic of the Plan, the gold reserves of the entire global economy would eventually converge into the ICB's vaults. As to the uses to which this mass of gold could then be put, Keynes suggested international aid. 